\title{
DAMPAK PENGALAMAN BERORGANISASI TERHADAP PERKEMBANGAN KARIR DAN JIWA KEPEMIMPINAN DI KALANGAN MAHASISWA (Studi Kualitatif di Kampus Institut Bisnis Muhammadiyah Bekasi)
}

\author{
DJIHADUL MUBAROK ${ }^{1}$, EVA FAUZIANA ${ }^{2}$ \\ djihadulmubarok@ibm.ac.id' ${ }^{1}$, eva.fauziana@ibm.ac.id ${ }^{2}$
}

Program Studi Ekonomi Pembagunan ${ }^{1}$, Program Studi Manajemen ${ }^{2}$ Institut Bisnis Muhammadiyah Bekasi

\begin{abstract}
This study discusses the impact of organizational experience while in college on career development and leadership spirit among students. Qualitative study by taking 84 students as respondents at the Bekasi Muhammadiyah Business Institute campus in the period February 2021. This study uses a questionnaire as the main tool in collecting opinions. The results of this study are, students who actively participate in student organization activities or when they are in the same school as OSIS, have a greater chance of being accepted for work, and have a wider perception of positive leadership styles.
\end{abstract}

Keywords: Organization experiences, Leadership, Career development

\section{PENDAHULUAN}

\section{Latar Belakang}

Mengisi waktu luang dengan kegiatan positif yang bermanfaat bagi masa kini dan masa depan generasi muda, adalah kewajiban seluruh pemangku kepentingan yang ada di lingkungan generasi muda itu sendiri. Tak hanya orang tua, guru, dosen dan mahasiswanya sendiri, namun masyarakat sekitar wajib bertanggung jawab terhadap kegiatan apa saja yang mereka lakukan di waktu luang.

Di masa pandemi Covid 19 yang mewajibkan social distancing serta meminimalisir kegiatan luring, di satu sisi memberi dampak positif bagi para mahasiswa. Dampak positif secara umum antara lain, masyarakat lebih peduli terhadap kesehatan dan kebersihan, adanya kerjasama di masyarakat untuk memberantas pandemi, kualitas udara membaik karena berkurangnya polusi akibat kendaraan bermotor, dan yang terakhir, adanya waktu luang yang cukup untuk menekuni hobi masing-masing (Career Sumarecon: 2021). 


\section{Gambar 1 Sisi Positif Covid 19}

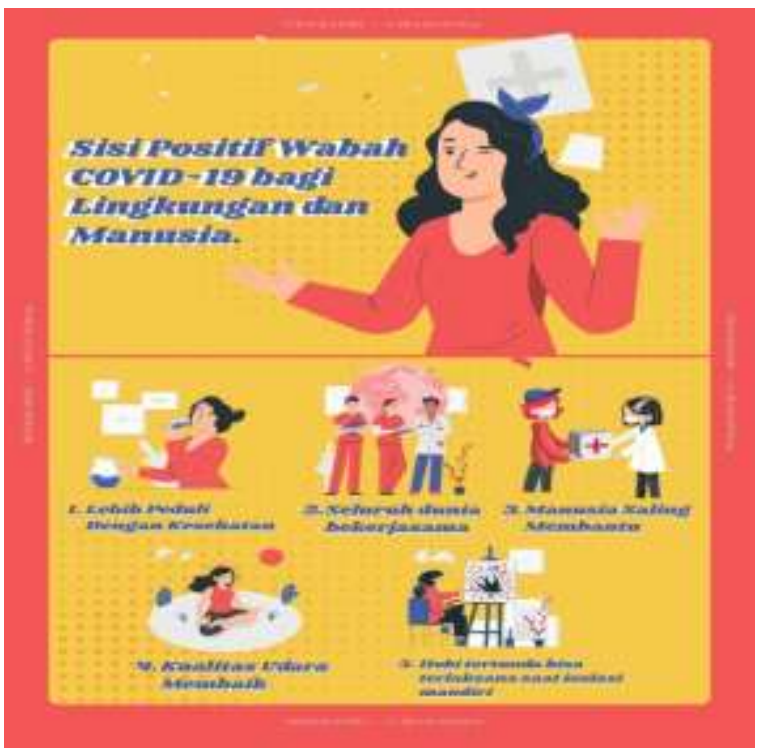

https://career.summarecon.com/blogs/3980/infografis -sis i-positif-wabah-covid-19-bagi-lingkungandan-manusia

Namun, dampak negatif dari pandemi, selain tentu saja korban sakit dan meninggal dunia dari virus ini terus meningkat, adalah adanya tingkat kriminalitas yang terus meningkat. Para remaja yang terbiasa menghabiskan sebagian besar waktu mereka di kampus atau di tempat kerja, kini memiliki kelebihan waktu luang, yang bila tak dimanfaatkan dengan baik dan tanpa kontrol yang ketat dari orang tua dan lingkungan, dapat menjerumuskan mereka kepada kegiatan yang merusak diri seperti kecelakaan karena balap liar, terpapar radiasi karena terlalu banyak bermain game online, hingga menjadi pencandu narkoba dan miras karena salah pergaulan dan terlalu banyak nongkrong, alias berkumpul di suatu tempat tanpa kegiatan positif yang terorganisir, hingga terlibat seks bebas yang mengakibatkan terpapar penyakit kelamin hingga HIV AIDS. 
Hal tersebut tergambar dari grafik di bawah ini bahwa memang kriminalitas terus meningkat - terutama di pekan ke-35 setelah Covid 19 mewabah, kejahatan naik hingga $4 \%$ menurut data kepolisian di bawah ini: (Koran Tempo: September 2020).

\section{Gambar 2 Angka Kriminalitas Semasa Pandemi Covid 19}

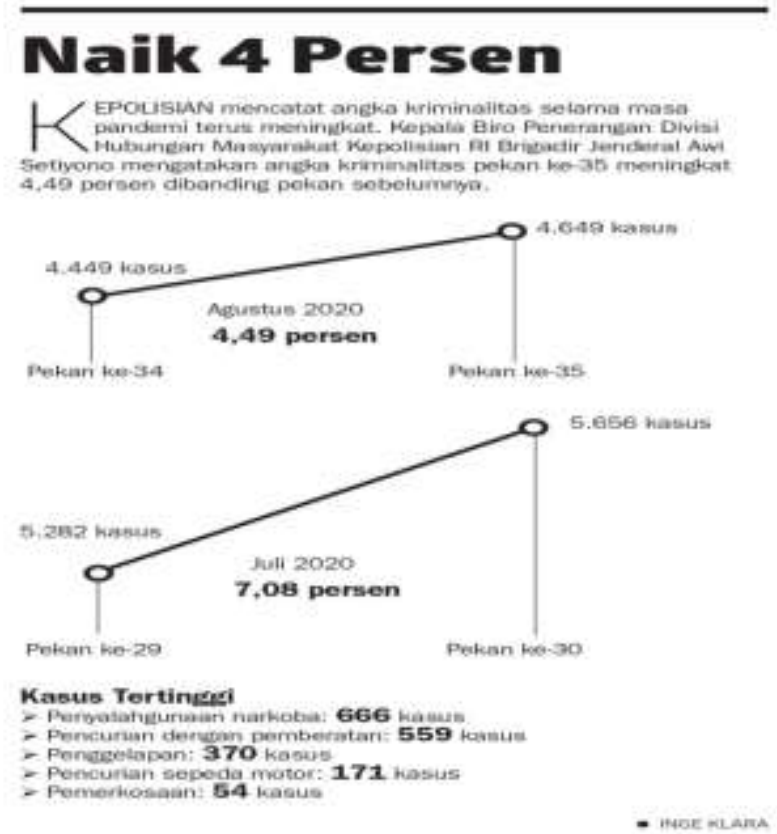

https://koran.tempo.co/read/metro/457569/kriminalitas -men ingkat-selama-masa-pandemi

Sedangkan di wilayah Bekasi sendiri, angka kejahatan meningkat pada tahun 2020, dan lonjakannya mencapai $25 \%$. Namun dengan catatan, kasus kejahatan terbesar ada pada curanmor, pemerasan, perkosaan, dan penganiayaan berat. Adapun kenakalan remaja tidak tercatat dalam catatan kepolisian Bekasi. (Bekasi Pojok Satu: Januari 2021).

Keberhasilan pemerintah Bekasi dalam menanggulangi kenakalan remaja dan meminimalisirnya hingga mencapai angka $0 \%$ (nol persen) memang tak lepas dari kerja keras serta kontribusi seluruh elemen masyarakat di daerah Bekasi, terutama kerja sama antara pemerintah Bekasi dengan institusi pendidikan formal dan informal serta kontrol yang cukup ketat dari masyarakat Bekasi itu sendiri.

Tak hanya mendukung kegiatan kepemudaan di lingkup Bekasi secara moral dan psikis, namun secara fisik dan material, pemerintah kota Bekasi sedanga membangun gedung yang khusus mewadahi kegiatan kepemudaan di wilayah ini, yang disebut dengan Gedung Creative Center di daerah Bekasi Timur (www.bekasikota.go.id: Januari 2019). 
Di wilayah Bekasi sendiri, tercatat 499 organisasi kepemudaan yang terdaftar di data base Pemerintah Kota Bekasi yang bergerak di wilayah sosial nonkomersial. Sedangkan tercatat 265 organisasi kepemudaan yang fokus pada kegiatan UMKM kewirausahaan (http://dispora.jabarprov.go.id). Hal tersebut menunjukkan dukungan penuh dari pemangku kepentingan akan giat positif kepemudaan, yang secara langsung dan tidak langsung juga mendukung kegiatan positif generasi muda yang berdampak positif pada rendahnya angka kenakalan remaja di daerah Bekasi.

\section{Rumusan Masalah}

Adapun rumusan masalah dalam penelitian ini adalah:

1. Bagaimana pemetaan kegiatan mahasiswa IBM Bekasi selain belajar di kampus, baik secara daring maupun luring?

2. Bagaimana dampak dari keaktifan mahasiswa berorganisasi?

\section{Tujuan Penelitian:}

Adapun tujuan dari penelitian ini adalah:

1. Memetakan kondisi mahasiswa IBM Bekasi dalam hal kegiatan mereka di luar jam perkuliahan.

2. Menganalisis sejauh mana kegiatan berorganisasi berdampak pada perkuliahan mereka.

3. Menganalisis sejauh mana kegiatan berorganisasi berdampak pada pekerjaan mereka.

\section{Manfaat Penelitian:}

Adapun manfaat dari penelitian ini adalah:

1. Memberi masukan bagi para mahasiswa dampak dari kegiatan berorganisasi.

2. Memberi masukan kepada lembaga institusi IBM Bekasi akan kegiatan berorganisasi di lingkup mahasiswa.

\section{TINJAUAN PUSTAKA}

\section{Pengertian Organisasi}

Menurut James. D. Mooney, organisasi adalah bentuk setiap perserikatan manusia untuk mencapai tujuan bersama. Dari pendapat tersebut dapat kita analisis bahwa setiap kumpulan manusia itu bertujuan langsung atau tidak langsung untuk memenuhi kebutuhan diri dan kelompok.

\section{Pengalaman Berorganisasi}

Mengutip dari hasil penelitian Diva Yurian Dwika, et.al yang berjudul "HUBUNGAN PENGALAMAN BERORGANISASI DENGAN TINGKAT ADVERSITY QUOTIENT (AQ) PADA MAHASISWA ANGKATAN 2012 FAKULTAS KEDOKTERAN UNIVERSITAS RIAU" ada korelasi positif antara mahasiswa kedokteran yang aktif berorganisasi dengan kecerdasan $A Q$ (adversity quotient) mereka, yaitu kecerdasan saat menghadapi tantangan baru, ketangguhan mengatasi kesulitan serta kecerdasan mengatasi seluruh kesulitan menjadi peluang sukses bagi mereka.

Penelitian tersebut juga menyaranakan pada seluruh mahasiswa di Fakultas 
Kedokteran Universitas Riau untuk terlibat dan beraktivitas positif dalam seluruh kegiatan organisasi manapun yang memiliki kegiatan positif, demi keberhasilan studi mereka, keberhasilan karir mereka setelah lulus kuliah kedokteran, serta keberhasilan mereka saat terjun ke masyarakat (Diva Yurian Dwika: 2012).

Dari hal tersebut di atas, terlihat jelas bahwa aktif dalam organisasi mendukung kegiatan perkuliahan, sekaligus menopang karir di masa depan, karena adanya jiwa kepemimpinan yang terasah yang bermanfaat untuk peningkatan karir, luasnya jaringan koneksi yang bermanfaat untuk saling bantu dan bekerja sama serta bersinergi dalam bidang usaha, serta wadah untuk penyaluran hobi, minat dan bakat, yang juga membuat pikiran serta emosi dalam keadaan positif.

\section{Perkembangan Karir}

Ardiyansyah, dkk (2018) mengutip pendapat Mathis (2006: 342) karir adalah rangkaian posisi atau jabatan yang berkaitan dengan pekerjaan yang ditempuh seseorang sepanjang hidupnya.

Dalam jurnal yang sama yang berjudul PENGARUH KEPEMIMPINAN,

MOTIVASI DAN DISIPLIN
TERHADAP KINERJA YANG BERDAMPAK PADA PENGEMBANGAN KARIR, Ardiansyah dkk (2018) mengutip uraian Rivai (2005: 291-297 pengembangan karir adalah suatu proses peningkatan kemampuan kerja individu malalui bimbingan, arahan, on the job training, pelatihan dan pendidikan untuk mencapai karir yang diinginkan oleh karyawan atau yang direncanakan oleh perusahaan.
Merangkum dari tulisan di beranda Ma'soem University Bandung (September 2020) berikut beberapa manfaat bila mahasiswa aktif dalam kegiatan berorganisasi:

1. Melatih jiwa kepemimpinan

2. Memperluas koneksi

3. Wadah minat

4. Mengasah bakat

Ardiansyah, dkk (2018) juga merangkum pendapat Suastha (2006:46) bahwa pengembangan (karir/jabatan) merupakan fungsi dari semua komponen sumber daya manusia, antara lain hasil dari rekruitmen dan seleksi yang baik, penempatan yang tepat, memiliki kemampuan melaksanakan tugas-tugas (kinerja) yang ditetapkan dalam struktur, mendapatkan kompensasi (reward) yang pantas, adanya pembinaan karyawan dalam peningkatan kinerja untuk jabatan yang sekarang dan dipersiapkan untuk jabatan yang akan diduduki di kemudian hari.

\section{Jiwa Kepemimpinan}

Mailani Hamdani mengutip Wunsanto dalam Sholehuddin (2008), mengutip bahwa mengapa seseorang memiliki jiwa kepemimpinan, antara lain: 
1) Teori Kelebihan

Menurut teori ini, seseorang menjadi pemimpin karena ia memiliki kelebihan- kelebihan dibanding yang lain. Dalam hal ini, kelebihan yang harus dimiliki oleh seorang pemimpin minimal tiga kelebihan, yaitu kelebihan ratio, kelebihan rohaniah dan kelebihan badaniah.

2) Teori Sifat

Menurut teori ini, menjadi pemimpin yang baik, seseorang harus memiliki sifat-sifat yang lebih daripada yang dipimpinnya. Sifat-sifat kepemimpinan yang secara umum harus dimiliki seperti sikap melindungi, percaya diri, inisiatif, persuatif, komunikatif, energik, kreatif, inovatif dan tanggung jawab.

3) Teori Keturunan

Teori ini menyatakan bahwa seseorang menjadi pemimpin karena keturunan atau warisan.

4) Teori Kharismatis.

Teori ini menyatakan bahwa untuk menjadi pemimpin seseorang harus mempunyai kharisma (pengaruh) yang sangat besar.

5) Teori Bakat.

Teori ini menyatakan bahwa seseorang menjadi pemimpin karena ada bakat didalamnya.

6) Teori Sosial.

Menurut teori ini, pada dasarnya setiap orang dapat menjadi pemimpin tanpa didasarkan atas bakat dan keturunan, asalkan orang tersebut diberi kesempatan untuk memimpin.

Dari uraian tersebut di atas, dapat kita analisis bahwa jiwa kepemimpinan hadir atau lahir karena adanya stimulus berupa kebiasaan positif seperti percaya diri, komunikatif, bertanggung jawab serta mengambil kesempatan memimpin lewat kebiasaan berorganisasi.

\section{Kerangka Berpikir}

Dari beberapa pendapat atau teori yang telah penulis jabarkan di atas, berikut kerangka teori yang menjadikan acuan bagi penelitian ini:

\section{Gambar 3 Kerangka Berpikir}

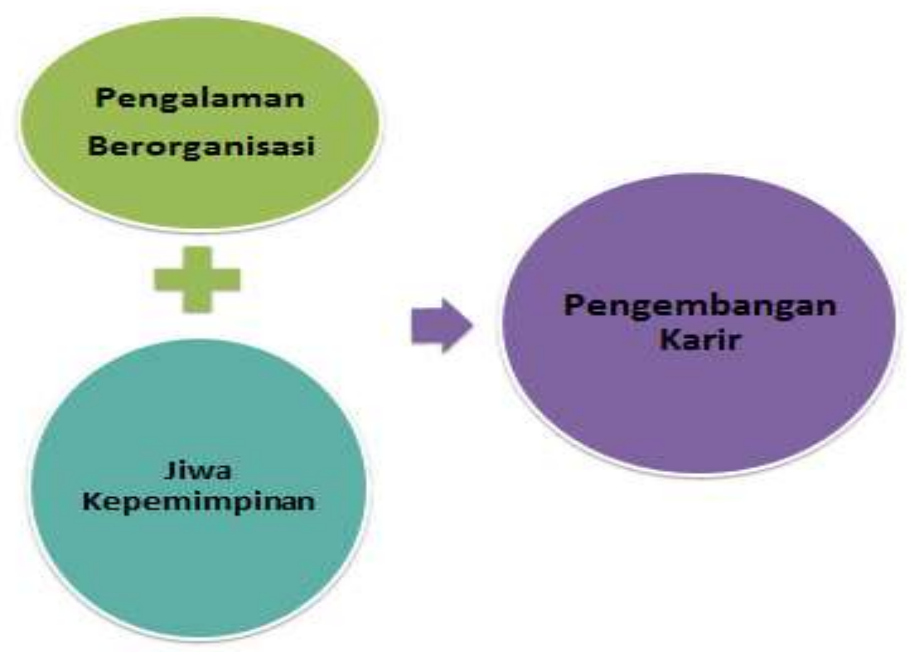


Dari beberapa teori atau hasil penelitian yang telah penulis kemukakan di atas, terlihat bahwa pengalaman berorganisasi memiliki dampak positif terhadap terasahnya jiwa kepemimpinan yang pada akhirnya juga memilki dampak positif pada perkembangan karir generasi muda.

\section{METODOLOGI PENELITIAN}

\section{Metode}

Menggunakan dasar penelitian kualitatif dengan cara menganalisis hasil kuesioner yang disebar secara online kepada mahasiswa.

\section{Lokasi \& Waktu Penelitian}

Penelitian ini berlokasi di kampus Institut Bisnis Muhammadiyah Bekasi pada periode Februari 2020.

\section{Responden}

Adapun responden dalam penelitian ini adalah 84 mahasiswa semester genap di tahun ajaran 2020/2021 yang bersedia mengisi kuesioner secara volunteer.

\section{PEMBAHASAN}

Data responden mahasiswa IBM Bekasi berdasakan kelompok umur:

Grafik 1 Rentang Usia Responden

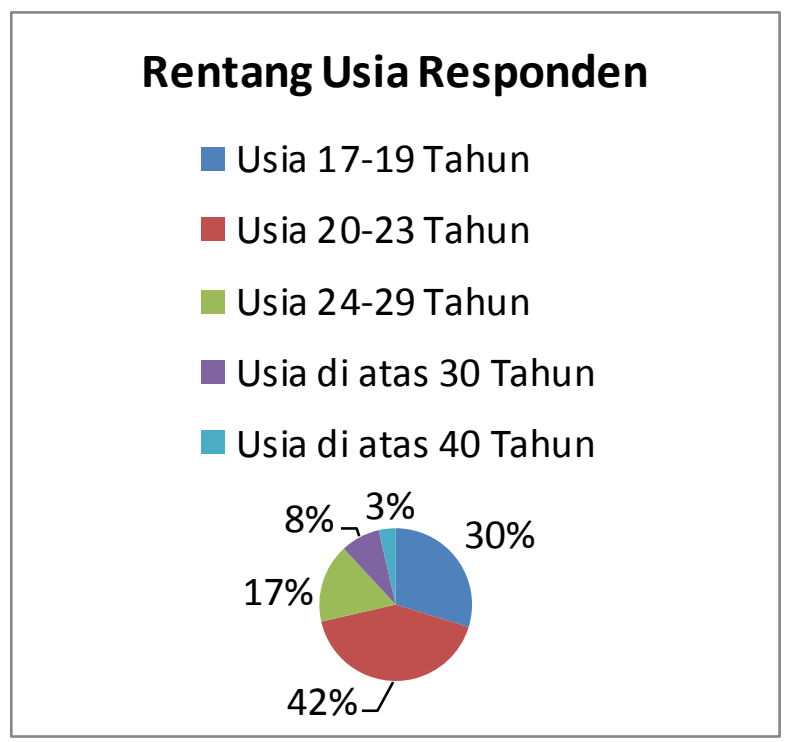

Sumber data pribadi diolah sendiri

Dari grafik 1 tersebut di atas, dapat kita analisis bahwa $75 \%$ lebih responden berada di usia dewasa muda dan dalam masa produktif, baik dari sisi pendidikan maupun produktif dalam mencari penghasilan sendiri. 
Grafik 2 Kegiatan Responden Saat Ini

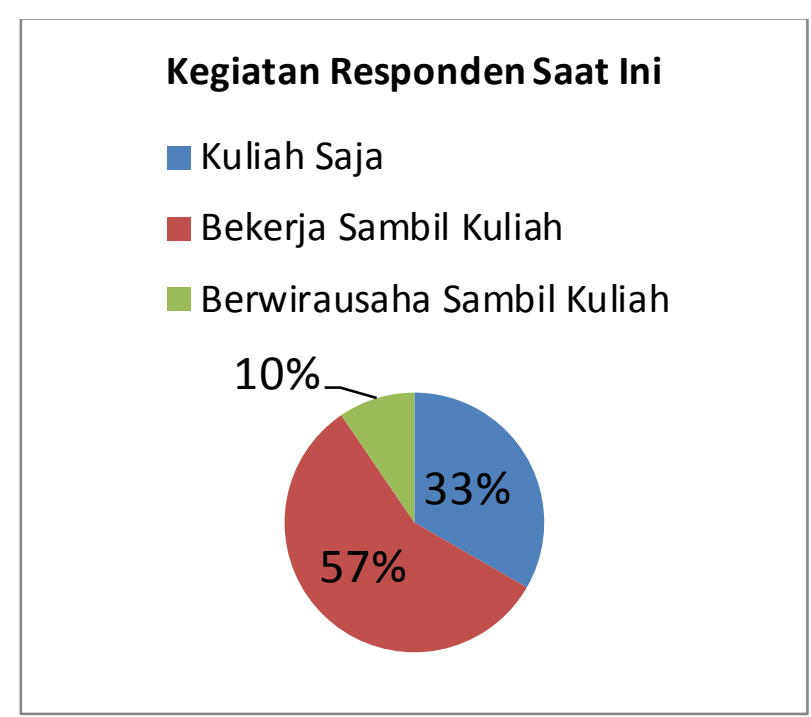

Sumber data pribadi diolah sendiri

Dapat kita analisis bahwa 57\% lebih responden aktif bekerja sambil kuliah, dan $33 \%$ responden menjalankan wirausaha sambil kuliah, dan sisanya sebesar $33 \%$ hanya fokus pada kegiatan perkuliahan saja.

Grafik 3 Keaktifan Dalam Berorganisasi

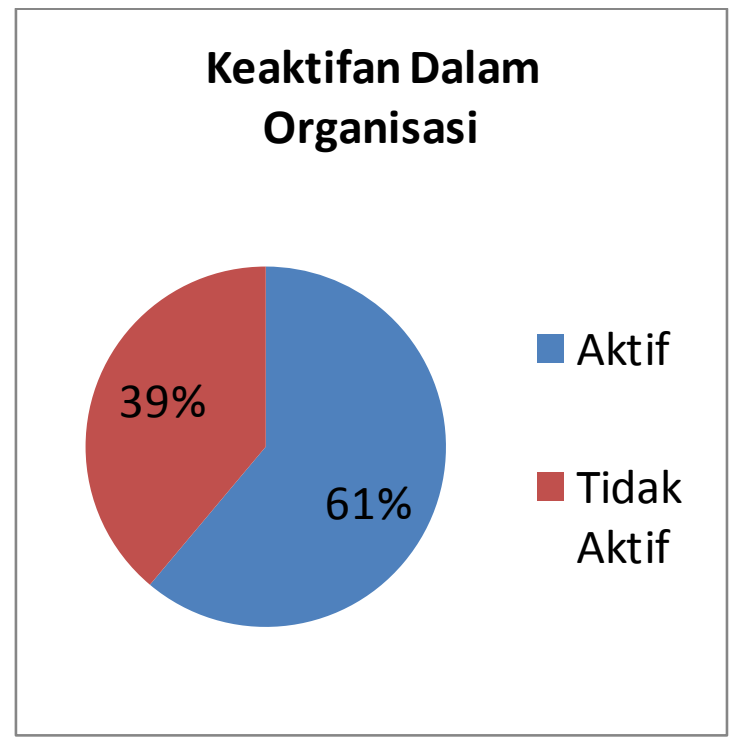

Sumber data pribadi diolah sendiri 
Dari $57 \%$ mahasiswa yang telah mendapatkan pekerjaan tersebut, menyatakan bahwa $61 \%$ nya masih aktif atau pernah aktif dalam kegiatan organisasi.

Kegiatan organisasi yang pernah mereka ikuti antara lain BEM (Badan Eksekutif Mahasiswa, Organisasi berbasis massa, Serikat Pekerja di kantor masing-masing. $10 \%$ sisanya mahasiswa yang kuliah sambil bekerja, mengatakan bahwa mereka tidak pernah aktif dalam kegiatan organisasi manapun.

Data tersebut dapat ditelaah dalam grafik 4 di bawah ini:

\section{Grafik 4 Jenis Organisasi Yang Diikuti Responden}

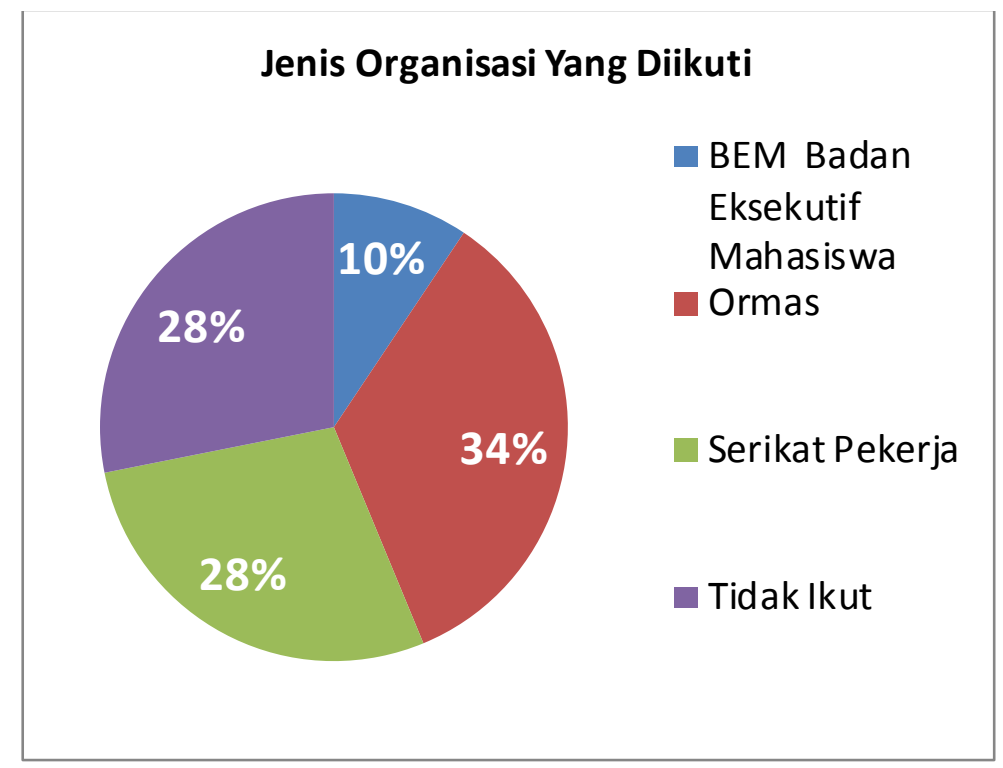

Sumber data pribadi diolah sendiri

Dari kegiatan organisasi yang mereka ikuti, hanya $4 \%$ yang memegang posisi strategis sebagai ketua atau pemimpin organisasi. Yang bertugas sebagai pengurus inti dalam setiap organisasi yang merekea geluti sejumlah $26 \%$ dan sisanya, sebanyak $70 \%$ mengambil peran sebagai anggota aktif. 
Grafik 5 Posisi Responden Dalam Organisasi

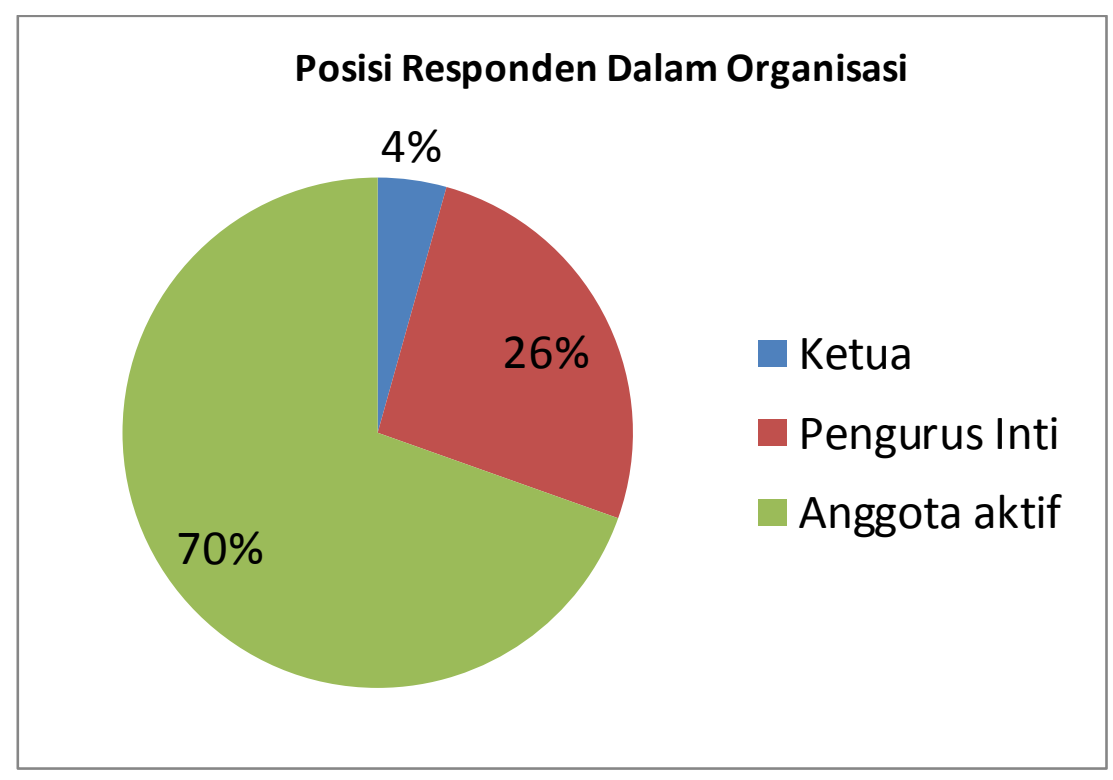

Sumber data pribadi diolah sendiri

Dari grafik 5 di bawah ini, dapat kita lihat bahwa, fokus mahasiswa yang kuliah sambil bekerja adalah tetap mengutamakan studi dan pekerjaan utama mereka.

Adapun kegiatan organisasi tetap mereka jalani meski tidak memegang posisi penting, hanya sebagai anggota aktif saja. Namun tetap menjadi poin positif bahwa setelah bekerja, mereka mengutamakan skala prioritas dan sudah pandai mengatur manajemen waktu mereka.

\section{Grafik 6 Mahasiswa Yang Berwirausaha dan Berorganisasi}

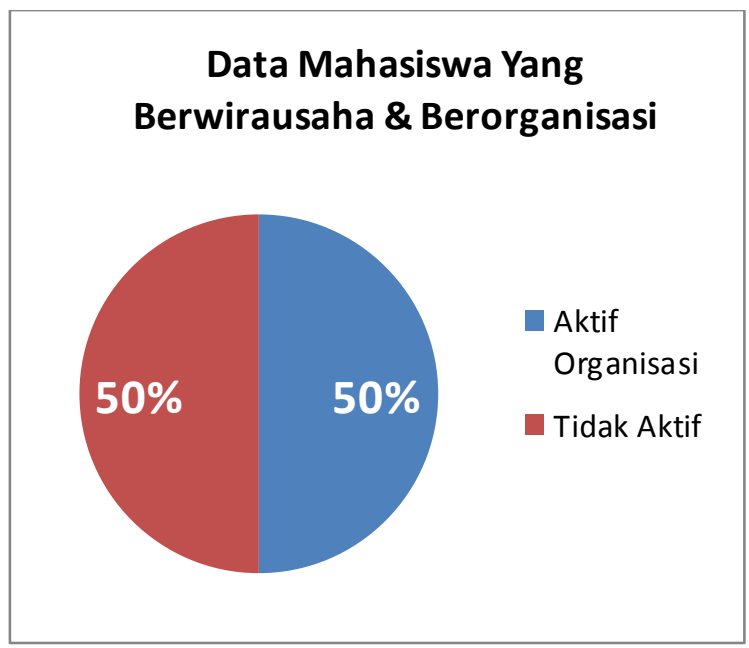

Sumber data pribadi diolah sendiri 
Uniknya, mahasiswa yang memiliki kegiatan berwirausaha saat kuliah, memiliki pilihan yang sebanding, antara yang aktif dan tidak aktif berorganisasi. Yang aktif berorganisasi berpendapat, lingkar pertemanan dalam organisasi dapat membantu pengembangan usaha UMKM mereka. Adapun yang memilih untuk tidak aktif berorganisasi. Berpendapat bahwa mereka kesulitan mengatur waktu bila harus tetap berkecimpung dalam organisasi. Hal tersebut tergambar dalam grafik 6 di atas.

\section{Grafik 7 Kegiatan Mahasiswa Hanya Fokus Kuliah}

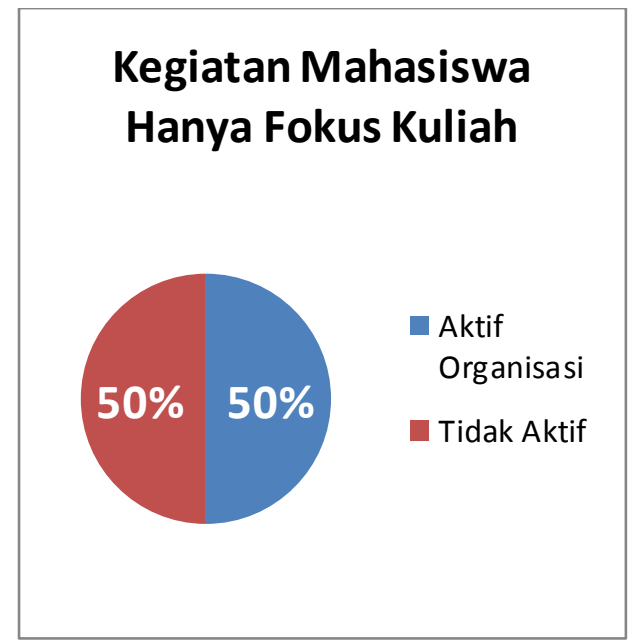

Sumber data pribadi diolah sendiri

Dari grafik 7 di atas menggambarkan bahwa mahasiswa yang hanya fokus pada kuliah saja, 50\% masih terlibat aktif dalam organisasi, dan 50\% lainnya mengatakan tidak aktif sama sekali. Yang aktif berorganisasi memilih BEM (Badan Eksekutif Mahasiswa) sebagai wadah berorganisasi, dan sisanya memilih kegiatan kepemudaan dan kerohanian islam di sekitar rumah sebagai wadah mereka berorganisasi.
Yang memilih tidak aktif memberikan alasan dilarang berkegiatan atau harus membatasi kegiatan selama pandemi oleh orang tua masing-masing. Mahasiswa yang hanya fokus kuliah saja ini memang 90\% berada di rentang usia 17-19 tahun, dan masih tinggal dengan orang tua masingmasing. 


\section{KESIMPULAN DAN SARAN}

\section{Kesimpulan}

Kesimpulan dari penelitian di atas antara lain adalah:

1. Mahasiswa yang aktif berorganisasi, biasanya memiliki peluang lebih besar untuk diterima bekerja meski status mereka masih aktif kuliah.

2. Mahasiswa yang aktif berorganisasi memiliki jiwa kepemimpinan dan terbukti dari jabatan yang mereka emban dalam organisasi yang mereka ikuti.

3. Mahasiswa yang aktif berorganisasi lebih pandai mengatur waktu antara kuliah, kerja hingga aktif berorganisasi.

4. Mahasiswa yang aktif berorganisasi, lebih mandiri secara finansial dibanding mahasiswa yang hanya fokus pada kuliah saja.

5. Mahasiswa yang aktif berorganisasi memiliki citra diri yang positif.

6. Mahasiswa yang aktif berorganisasi juga berada dalam bagian mahasiswa produktif meningkatkan ekonomi pribadi lewat bekerja, atau

menigkatkan perekonomian rakyat lewat usaha UMKM yang mereka geluti.

\section{Saran}

Dari penelitian di atas, penulis mengemukakan saran sebagai berikut:
1. Institusi pendidikan wajib mendukung kegiatan positif mahasiswa dalam berorganisasi.

2. Institusi pendidikan, dalam hal ini Institut Bisnis Muhamamadiyah Bekasi, menyediakan wadah bagi mahasiswa untuk mengaktualisasikan dirinya dalam berorganisasi, dan mengaktifkan organisasi kepemudaan di lingkungan kampus, misalnya Nasyiatul Aisyiyah dan Ikatan Muda Muhammdiyah.

3. Kampus memberi penghargaan kepada mahasiswa yang aktif berorganisasi namun tetap berpretasi di bidang akademik.

4. Tetap memantau dan membimbing kegiatan mahasiswa dalam berorganisasi, agar kegiatan yang mereka lakukan tetap sesuai visi misi kampus. 


\section{DAFTAR PUSTAKA}

Ardiansyah, dkk. PENGARUH

KEPEMIMPINAN, MOTIVASI

DAN DISIPLIN

TERHADAP KINERJA YANG

BERDAMPAK PADA

PENGEMBANGAN KARIR.

http://stiepertiba.ac.id/ojs/inde

x.php/jem/article/view/3. 2018

Mailani Hamdani, MENUMBUHKAN

JIWA KEPEMIMPINAN

GENERASI MUDA

MELALUI KEWIRAUSAHAAN

(sebuah kajian teoritis)

http://repository.ut.ac.id/2350/1

/mailani_hamdani.pdf
Yurian, Diva, dkk. HUBUNGAN

PENGALAMAN

BERORGANISASI DENGAN

TINGKAT ADVERSITY

QUOTIENT (AQ) PADA

MAHASISWA ANGKATAN

$2012 \quad$ FAKULTAS

KEDOKTERAN UNIVERSITAS

RIAU

https://media.neliti.com/media/

publications/183627-ID-

hubungan-pengalaman-

berorganisasi-dengan.pdf

Pentingnya Pengalaman

Organisasi Bagi Mahasiswa

https://masoemuniversity.ac.id/

berita/pentingnya-pengalaman-

organisasi-untuk-

mahasiswa.php

https://www.bekasikota.go.id/detail/wa likota-bekasi-ingin-pemuda-proaktifdalam-pembangunan

https://koran.tempo.co/read/metro/457 569/kriminalitas-meningkat-selamamasa-pandemi

https://career.summarecon.com/blogs/3 980/infografis-sisi-positif-wabahcovid-19-bagi-lingkungan-danmanusia

http://dispora.jabarprov.go.id 